C. И. Абакумова [S. I. Abakumova]

II. IO. Ботвинева [N. Yu. Botvineva]

E. В. Гулынина [E. V. Gulynina]

\title{
СВОЙСТВА ОРТОГОНАЛЬНОСТИ И ПОЛНОТЫ СИСТЕМЫ
} СФЕРИЧЕСКИХ ФУНКЦИЙ

\section{THE PROPERTIES OF ORTHOGONALITY AND COMPLETENESS OF THE SYSTEM OF SURFACE HARMONICS}

Институт сервиса, туризма и дизайна (филиал) СКФУ в г. Пятигорске, Россия, e-mail: svetaabaku@rambler.ru/ North Caucasus Federal University, Institute of Service, Tourism and Design (branch) of NCFU in Pyatigorsk, Russia, e-mail: svetaabaku@rambler.ru

\begin{abstract}
Аннотация. С ферические функиии представляют собой угловую часть семейства ортогональных решений уравнения Лапласа, записанную в сферических координатах. Использование этих функиий достаточно разнообразно, они ииеют больиое зиачение в теории дифференциальньх уравнений в частиьх производньх и теоретической физике.

Материалы и метод, результаты и обсуждения. В статье доказывается ортогональность и полнота систель сферических функций вида (4). Сферическими функциями называют специальньее функции одного переменного, являющиеся решениями дифференциальных уравнений, получающихся при применении метода разделения переменньх для уравнения Лапласа, записанного е сферических координатах. Аеторами рассматривается разложение сферической функиии, иметощей непрерывные вторые производнье в ряд Фурье. В процессе такого разложения используется оператор сферических функиий, далее применяется метод интегрирования по частял на поверхности сферы. Записаны формулы Грина для оператора сферических функиий, анализ полученных результатов доказывает ортогональность сферических функиий. Впоследствии, рассматривал коэффициенты ряда Фурье, как непрерывные функиии и, доказывая возложность равномерной аппроксимации линейньми комбинациями присоединенньх функций любой дважды дифференцируемой функции $f(\theta, \varphi)$, доказывается полиота системь фуикиий, определяемьх формулой (4).

Заключение. В результате исследования выяснилось, что любую непрерывную функиию можно равномерно аппроксимировать полиномом сферических функций, что и доказыеает полноту системь функций, определяемьцх формулой (4). Нз полноть этой системь следует её замкнутость. Такии образом, доказано, что уравнение сферических функиий не имеет ограниченных решений при $\lambda \neq n(n+1)$ и что всякая сферическая функция $n$-го порядка $(n р и \lambda=n(n+1))$ nредставима формулой (5).
\end{abstract}

Ключевые слова: сферические функции, ортогональность и полнота сферических функций, сферическая гармоника.

Abstract. Surface harmonics represent the angular part of the family of orthogonal solutions of the Laplace equation, written in spherical coordinates. The use of these functions is quite diverse, they are of great importance in the theory of differential equations in partial derivatives and theoretical physics.

Materials and method, results and discussions. The article proves the orthogonality and completeness of a system of surface harmonics of the form (4). Surface harmonics are special functions of one variable that are solutions of differential equations obtained by applying the method of separation of variables for the Laplace equation written in spherical coordinates. The authors consider the decomposition of a surface harmonics having continuous second derivatives in a Fourier series. In the process of such decomposition, the operator of spherical functions is used, then the method of integration by parts on the surface of the sphere is used. Green's formulas for the operator of surface harmonics are written, an analysis of the obtained results proves the orthogonality of spherical functions. Subsequently, considering the coefficients of the Fourier series as continuous functions and proving the possibility of uniform approximation by linear combinations of the adjoint functions of any twice differentiable function $f(\theta, \varphi)$, and the completeness of the system of functions defined by formula (4) is proved.

Conclusion As a result of the study, it turned out that any continuous function can be uniformly approximated by a polynomial of surface harmonics, which proves the completeness of the system of functions defined by formula (4). From the completeness of this system follows its isolation. Thus, it is proved that the equation of surface harmonics does not have bounded solutions for $\lambda \neq n(n+1)$ and that any surface harmonics of the $n$-th order $($ for $\lambda=n(n+1))$ is representable by formula (5).

Key words: surface harmonics, orthogonality and completeness of surface harmonics.

Introduction. Let us write a system of $n$-th order surface harmonics. Let us agree to assign a negative superscript to those functions that contain $\cos (k \varphi)$, and a positive one to those functions that contain $\sin (k \varphi)$. Then we will have:

$$
(k=1,2, \ldots, n) .
$$

The number of different $n$-th order surface harmonics $Y_{n}^{(m)}$ is $2 n+1$. Linear combination of these $2 n+1$ surface harmonics (4)

or

$$
Y_{n}(\theta, \varphi)=\sum_{m=0}^{n}\left(A_{n m} \cos m \varphi+B_{n m} \sin m \varphi\right) P_{n}^{(m)}
$$

$$
Y_{n}(\theta, \varphi)=\sum_{m=-n}^{n} C_{m n} Y_{n}^{(m)}(\theta, \varphi),
$$

where $C_{m n}=\left\{\begin{array}{l}A_{n m} \text { for } m \leq 0, \\ B_{n m} \text { for } m>0 .\end{array}\right.$ is also a spherical function and is called a surface harmonic [3].

102 Выпуск №2, 2020 
Materials and methods. Let us prove the completeness of the system of surface harmonics defined by formula (4). First, let us prove that any function $f(\theta, \varphi)$ with continuous second derivatives can be uniformly approximated by some polynomial of surface harmonics.

Consider the expansion of such a function in a Fourier series

It is easy to see that we get the formula

$$
\begin{gathered}
f(\theta, \varphi)=\sum_{m=0}^{\infty}\left[A_{m}(\theta) \cos m \varphi+B_{m}(\theta) \sin m \varphi\right] \\
\Delta_{\theta, \varphi}=\frac{1}{\sin \theta} \frac{\partial}{\partial \theta}\left(\sin \theta \frac{\partial}{\partial \theta}\right)+\frac{1}{\sin ^{2} \theta} \frac{\partial^{2}}{\partial \varphi^{2}}
\end{gathered}
$$

$$
\iint_{\Sigma} Y_{2} \Delta_{\theta, \varphi} Y_{1} d \Omega=-\iint_{\Sigma}\left\{\frac{\partial Y_{1}}{\partial \theta} \frac{\partial Y_{2}}{\partial \theta}+\frac{1}{\sin ^{2} \theta} \frac{\partial Y_{1}}{\partial \theta} \cdot \frac{\partial Y_{2}}{\partial \theta}\right\} d \Omega
$$

easily obtained by integration by parts.

$$
(d \Omega=\sin \theta d \theta d \varphi)
$$

On the surface of a sphere

$$
\begin{gathered}
\text { gradu }=\frac{\partial}{\partial \theta} i_{\theta}+\frac{1}{\sin \theta} \frac{\partial u}{\partial \theta} i_{\varphi}, \\
\operatorname{div} A=\frac{1}{\sin \theta}\left[\frac{\partial}{\partial \theta}\left(\sin \theta A_{\theta}\right)+\frac{\partial A_{\varphi}}{\partial \varphi}\right]
\end{gathered}
$$

so that $\Delta_{\theta, \varphi} u=g r a n u$, and formula (9) can be written in the form

$$
\iint_{\Sigma} Y_{2} \Delta Y_{1} d \Omega=-\iint_{\Sigma} \operatorname{grad} Y_{1} \cdot \operatorname{grad} Y_{2} \cdot d \Omega
$$

Changing places in the formula (9) functions $Y_{1}$ и $Y_{2}$ and subtracting the resulting formula from formula (9), we will have:

$$
J=\iint_{\Sigma}\left\{Y_{2} \Delta_{\theta, \varphi} Y_{1}-Y_{1} \Delta_{\theta, \varphi} Y_{2}\right\} d \Omega=0
$$

Результаты и обсуждешия. Formulas (9) and (10) are Green's formulas for the operator of surface harmonics. The orthogonality of the functions $Y_{1}$ and $Y_{2}$. easily follows from formula (10). Indeed, using equation (8), we obtain from formula (10)

whence, for $\lambda_{1} \neq \lambda_{2}$

$$
J=\left(\lambda_{2}-\lambda_{1}\right) \iint_{\Sigma} Y_{1} Y_{2} d \Omega=0
$$

$$
\iint_{\Gamma} Y_{1} Y_{2} d \Omega=0
$$

or

$$
\int_{0}^{2 \pi} \int_{0}^{\pi} Y_{1}(\theta, \varphi) Y_{2}(\theta, \varphi) \sin \theta d \theta d \varphi=0
$$

This proves the orthogonality of surface harmonics corresponding to different $\lambda$

Above, we obtained for $\lambda=n(n+1)$ a system of $2 n+$ surface harmonics of the $n$-th order. Let us prove that these surface harmonics are orthogonal to each other on the sphere.

Let $Y_{n}^{\left(k_{1}\right)}$ and $Y_{n}^{\left(k_{2}\right)}$ be two surface harmonics. By integrating their products and using them, we get:

$$
\begin{gathered}
\iint_{\Gamma} Y_{n}^{\left(k_{1}\right)} Y_{n}^{\left(k_{2}\right)} d \Omega=\int_{0}^{2 \pi} \int_{0}^{\pi} Y_{n}^{\left(k_{1}\right)}(\theta, \varphi) \cdot Y_{n}^{\left(k_{1}\right)}(\theta, \varphi) \sin \varphi d \theta d \varphi= \\
\int_{0}^{2 \pi} \cos k_{1} \varphi \cos k_{2} \varphi d \varphi \int_{0}^{\pi} P_{n}^{\left(k_{1}\right)}(\cos \theta) P_{n}^{\left(k_{2}\right)}(\cos \theta) \sin \theta d \theta=
\end{gathered}
$$

Using the boundedness of the second derivative, it is easy to estimate the coefficients $A_{m}$ и $B_{m}$ of this decomposition

where $M=\max \left|f_{\varphi \varphi}\right|$.

$$
\left|A_{m}\right|<\frac{M}{m^{2}},\left|B_{m}\right|<\frac{M}{m^{2}}
$$

Hence it follows that the remainder of the Fourier series satisfies the uniform estimate

$$
\left|f-\sum_{m=0}^{m_{0}}\left[A_{m}(\theta) \cos m \varphi+B_{m}(\theta) \sin m \varphi\right]\right|=\left|R_{m_{0}}\right|<2 M \sum_{m=m_{0}}^{\infty} \frac{1}{m^{2}}<\varepsilon^{\prime},
$$

where $\varepsilon^{\prime}>0$ - any predetermined number.

Based on the closedness properties of the system of associated functions [4], the Fourier coefficients $A_{m}(\theta)$ and $B_{m}(\theta)$, which are continuous functions of $\theta$, vanishing at $\theta$ equal to 0 and $\pi$, can be uniformly approximated by linear combinations of associated $\mathrm{m}$-th order functions.

$$
\left|A_{m}(\theta)-\sum_{k=0}^{n} a_{k} P_{k}^{(m)}(\cos \theta)\right|<\frac{c \prime}{2 m_{0}+1},\left|B_{m}(\theta)-\sum_{k=0}^{n} b_{k} P_{k}^{(m)}(\cos \theta)\right|<\frac{c \prime}{2 m_{0}+1}
$$

Then from inequalities (11) and (12) it will follow:

$$
\left|f(\theta, \varphi)-\sum_{m=0}^{m_{0}} \sum_{k=0}^{n}\left[a_{k} P_{k}^{(m)}(\cos \theta) \cos m \theta+b_{k} P_{k}^{(m)}(\cos \theta) \sin m \theta\right]\right|<2 \varepsilon^{\prime}
$$

This proves the possibility of uniform approximation of any twice differentiable function $f(\theta, \varphi)$ by a polynomial of spherical functions.

Conclusion. Any continuous function can be uniformly approximated by a polynomial of surface harmonics, which proves the completeness of the system of functions defined by formula (4). The completeness of this system im- 
plies that it is closed. Thus, we have proved that the equation of surface harmonics has no bounded solutions for $\lambda \neq n(n+1)$ and that any $n$-th-order surface harmonics (for $\lambda=n(n+1)$ ) can be represented by formula (5). Obviously, the surface harmonics are the values of the surface harmonics (6) and (7) on the sphere of radius one.

\section{ЛИТЕРАТУРА}

1. Араманович И.Г., Левин. В.И. Уравнения математической физики. М.: Наука, 1969. 288 с.

2. Владимиров В.С. Уравнения математической физики. М. : Физматлит, 2004. 398 с.

3. Гибсон Е.В. Теория сферических и эллипсоидальных функций. М.: ИЛ, 1952. 476 с.

4. Гулынина Е.В. Свойства разложения произвольных функций по сферическим. Сб Актуальные вопросы современной науки. Сб. научных докладов 21 -ой научно-практической конференции. 2015. С. 150-153.

\section{REFERENCES}

1. Aramanovich I.G., Levin. V.I. Uravneniya matematicheskoj fiziki. M.: Nauka, 1969. 288 s.

2. Vladimirov V.S. Uravneniya matematicheskoj fiziki. M. : Fizmatlit, 2004. 398 s.

3. Gibson E.V. Teoriya sfericheskih i ellipsoidal'nyh funkcij. M.: IL, 1952. $476 \mathrm{s.}$

4. Gulynina E.V. Svojstva razlozheniya proizvol'nyh funkcij po sfericheskim. Sb Aktual'nye voprosy sovremennoj nauki. Sb. Nauchnyh dokladov 21 oj nauchno-prakticheskoj konferencii. 2015. S. 150-153.

\section{OБ АВTOPAX | ABOUT AUTHORS}

Абакумова Свет.лана Ивановна, кандидат педагогических наук, доцент кафедры физики, электротехники и электроэнергетики, Институт сервиса, туризма и дизайна (филиал) СКФУ в г. Пятигорске.

Abakumova Svetlana Ivanovna, Candidate of Pedagogical Sciences, Associate Professor, Department of Physics, Electrical Engineering and Electric Power, Institute of Service, Tourism and Design (branch) of NCFU in Pyatigorsk.

Ботвинева Наталья Юрьевна, кандидат педагогических наук, доцент кафедры математики, информатики, Ставропольский государственный педагогический институт в г. Ессентуки. Botvineva Natalya Yuryevna, Candidate of Pedagogical Sciences, Associate Professor of the Department of Mathematics, Computer Science, Stavropol State Pedagogical Institute in Essentuki.

Ки,

Гу.лынина Елена В.ладимировна, кандидат физико-математических наук, доцент кафедры математи-

информатики, Ставропольский государственный педагогический институт в г. Ессентуки.

Gulynina Elena Vladimirovna, Candidate of Physical and Mathematical Sciences, Associate Professor of The Department of Mathematics, Computer Science, Stavropol State Pedagogical Institute in Essentuki. 